\title{
Cartographic Approach in Studying Landscape Northwestern of Part Western Siberia
}

\author{
Ekaterina Kuzmenko \\ Institute of geography, Russian Academy of Sciences, Siberian Branch, Irkutsk, Russia \\ Email: kuzmenko48@mail.ru
}

Received 29 May 2015; accepted 26 August 2015; published 31 August 2015

Copyright (C) 2015 by author and Scientific Research Publishing Inc.

This work is licensed under the Creative Commons Attribution International License (CC BY). http://creativecommons.org/licenses/by/4.0/

(c) (†) Open Access

\begin{abstract}
The structure and dynamics of geosystems: plant of forest and bogs in the northwestern part of Western Siberia is considered by using the Kazym-Lyamin interfluve, based on the landscape-assessment map for the middle part of the Khanty-Mansi Autonomous District. The study used the landscape structural-dynamical approach and the methods of studying the spatio-temporal dynamics of taiga geosystems. Theoretical and methodological research on the development of the landscape-assessment map for Asian Russia is high on the cartographic agenda of the V. B. Sochava Institute of geography SB RAS. The methodic research is to be used to Landsat-5 TM in GIS MultiSpec and Qgis. An analysis is also made of the topographic, geomorphologic and forest 1:200,000 maps, the profiles characterize the lithology, field data of geobotanical and soil de- scriptions, and experimental permanent station operated. The landscape structure of this area and its hierarchical subordination are represented in the map legend in terms of groups of facies which are combined into regional-typological classification units: groups of geoms, classes, and types of natural environment. Landscape mapping and planning will help to timely prevent and forecast the magnitudes of disturbances to natural environment using and be as the basis for a package of optimal nature-conservation measures and target-oriented technogenic and anthropogenic impacts.
\end{abstract}

\section{Keywords}

Geosystems, Landscape Map, Successional Dynamics Plant

\section{Introduction}

The ongoing landscape mapping of the taiga in the northwestern part of Western Siberia is based on the methods of geosystem analysis being developed further; geosystem analysis is known as the theory of geosystems which is put forth by academician V. B. Sochava [1]. According to V. S. Mikheev [2], within the framework of such an 
approach, the landscape map must serve as a guide to the movement of state variables of geosystems at the topological level of detail. This provides a means of using the landscape map in ecologo-geographical forecasting, cartographic modeling, the creation of assessment maps, in solving the issues relating to geosystem stability and ecological zoning of territories for a variety of purposes. Furthermore, the goal of implementation of the landscape approach is to identify all natural categories of structural-dynamical differentiation of landscape and to determine the main element in the process of multiple dynamical changes.

One such test region for the creation of such a map is the northwestern part of Western Siberia as one of the largest oil- and gas-bearing regions of Asian Russia which has faced the problem of rehabilitating and protecting the landscapes on the territory measuring tens and hundreds of square kilometers, disturbed due to the exploitation of oil and gas fields. Landscape mapping of the regions in Western Siberia has received too little attention to date. Further still the existing dynamical landscape classifications are almost entirely neglected. This paper is concerned with the problem of studying and mapping the structure and some aspects of the dynamics of geosystems in the processes of compiling the landscape-assessment map for the middle part of the Khanty-Mansi Autonomous District (KhMAD).

The map is analyzed by using the Kazym-Lyamin interfluve as an example.

The map legend was compiled having regard to the state variables of facies for factoral-dynamical or ecologosuccessional series. Earlier publications investigated sequences and series of transformation of facies from hypertrophied factors (lithomorphic, hydromorphic, etc.) on field features [2]. Spatial-functional interactions of geosystems were also taken into consideration.

A further important issue was the problem of reveiling and displaying on the map the invariant structure as a generalization of variable states of geosystems predominantly in the wake of anthropogenic or natural disturbances. For taiga geosystems, a study was made of the recovery-age successional (demutational) cycles [3] [4]. This approach made it possible to develop the map legend as an analog-situational model for different factoraldynamical and recovery-age spatiotemporal series.

As pointed out by V. B. Sochava [1], particular attention must be attached to the spatial analysis of dynamical phenomena by generating analytical and synthetic maps, but little consideration has been given to the reflection of the dynamics on maps to this day.

\section{Data and Methods}

\subsection{Study Area and Idea Classification of the Forests}

Theoretical and methodological research on the development of the landscape-assessment map for Asian Russia is high on the cartographic agenda of the V. B. Sochava Institute of geography, Siberian Branch, Russian Academy of Sciences [1]-[4].

Assessments of forest cover are particularly necessary, as it is the most disturbed part of the taiga landscape in consequence of intensive tree cutting, fires and other damaging factors. The nearest-term forest cover changes are determined by the recovery-age dynamics of forest facies or of their typological groups through derivative successional changes where plant communities recover to native ones. Such a situation, as described by V. B. Sochava [1], is closely allied to the notion of the invariant of geosystems, and to the study of successions and equifinal (stable) states. The investigative technique for the recovery-age dynamics of taiga geosystems on territory was developed in the process of studying the middle-taiga forests in Western Siberia [4]. As part of a large-scale mapping of the key areas, classification schemes of landscape facies and forest types were prepared having regard to their differentiation according to topographic features, the character of humidification and dynamical states. They are included in the legend to the landscape map thus transforming it to the landscape-assessment map legend. The additions are italicized, with lettering added: 1) short-lasting derivative; 2) long-lastingly derivative; and 3) stably derivative or transformed.

For Western Siberia where it is highly appropriate to take into account the transformation of all landscapes, a specific feature of the approach to compiling such maps is the analysis of the structures of spatial-functional interaction. Also, it is important to display the changes not only for the main series of geosystems on drained watersheds but also in different situations of contact of landscape spheres: bog-taiga, floodplain-taiga, bog-floodplain, bog-taiga-floodplain, and so on, which permits us to define the partial geosystems as systems of replacement under the influence of changes occurring in surrounding landscapes. 


\subsection{Sampling Methods}

The landscape-assessment map was compiled in two stages. The first stage involved developing the 1:1,000,000 landscape map for the middle part of the KhMAD using the two-series principle of classification of geosystems, namely from the chorological series, and from the geomer series. The landscape structure of this area and its hierarchical subordination are represented in the map legend in terms of groups of facies which are combined into regional-typological classification units: groups of geoms, classes, and types of natural environment. The map compilation technique is detailed in a monograph [5].

The landscape-assessment map, including the territory of the Kazym-Lyamin interfluve, scaled up to 1:1,500,000, is presented in Figure 2.

The problem becomes more involved in the case of generating the landscape-assessment map, because this requires analyzing the degree of disturbance of landscapes, including their vegetation cover, and determining the degree of their transformation and stability [6]. Of significant importance in this regard is the reflection of the invariant organization of geosystems where an assessment is made of their spontaneous and anthropogenic variability, and of the preservation of vegetation structure and composition and of the main landscape components.

An important issue is related to the possibility of reflecting the dynamics of geosystems by switching over to the level of general-purpose mapping. A scale of 1:500,000 was used as the working scale, which dictated a need to select for map compilation a higher classification category than the group of facies. The advisability of using a different level of data handling, namely a class of landscape facies, stems from the necessity of adhering to the principle of cartographic generalization as formulated by A. M. Berlyant [7]. The essence of this principle is thus: with decreasing map scale, the transition from lower to higher classification units is accomplished.

The geom is complicated to use as the main "starting" unit of mapping, although this unit approaches the regional level of generalization. Yet the geom is less informative as regards the reflection of the various dynamical situations in landscape. An electronic processing of the landscape-assessment map for the territory using the state-of-the-art Maplnfo GIS technology was carried out by A. V. Bardash.

The map was compiled by using a classification; the current status of geosystems and classification were updated according to Landsat-5 TM space images (Figure 1).

An analysis to Landsat-5 TM used GIS MultiSpec and Qgis. An analysis was made also of the topographic, geomorphologic and forest 1:200,000 maps, the profiles characterizing the lithology, field data of geobotanical and soil descriptions and experimental permanent station operated by, and experimental the Institute of Geography SB RAS. To assess the pattern of forest vegetation and its productivity for the tree layer used forest management data from the Khanty-Mansiiskii.

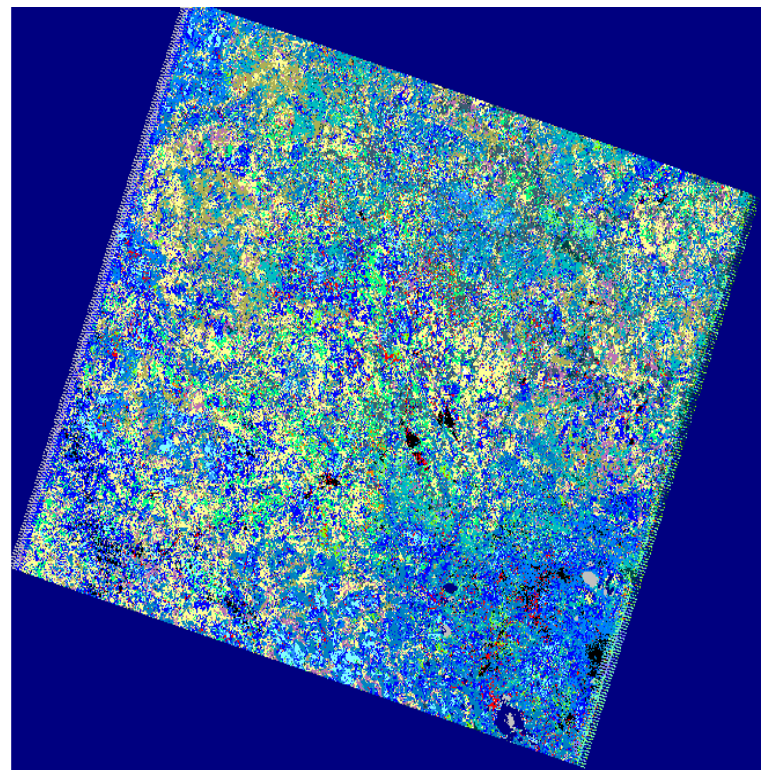

Figure 1. By clustering the Landsat image northwestern of part Western Siberia for using algorithm ESHO in GIS MultiSpec (Landsat 5 164-17). 


\section{Results}

On one hand, the landscape-assessment map must characterize a high level of regional-planetary generalization of natural geosystems; on the other, it must reflect the main spectrum of factoral-dynamical series and elements of successional recovery-age cycles as the model for invariants of geosystems at the topological level.

Upon combining facies groups into classes (192 groups of landscape facies were grouped together into 63 classes), the "bottom-up" geosystem approach made it possible to retain in the legend the structure of factoraldynamical series, though in a more generalized form when compared with the facies approach. For instance, the hydromorphic series, once generalized, is characterized by the following chain of facies classes: watershed treeless oligotrophic bogs (38)-> weakly drained watershed-slope ridgy-mire bogs and "ryams" (39) along-valley bogs with mixed-dark-coniferous swamped forests (40)-> patches of spruce-Siberian stone pine true-moss taiga amidst bogs (12) (Figure 2).

The recovery-age formation cycle of the Siberian stone pine taiga in the wake of disturbances is represented by the initial stage of its formation: spruce- birch, Siberian stone pine-spruce-birch derivative forests (12b), and by the final stage: native spruce-Siberian stone pine foxberry-true moss forests (12).

Thus the technique used in this study made it possible to sufficiently completely reflect the diversity and transformation patterns of the landscape structure in the middle part of KhMAD, to the maximum possible extent, and to proceed to a compilation of the landscape disturbance assessment map.

Let us consider the landscape structure and some aspects of the dynamics of the Kazym-Lyamin interfluve (Figure 2). Its northern part is mostly a swamped, territory characterized by facies classes of the arcto-boreal open woodland-bog class of geoms: permafrost flat-hummocky dwarf birch-sphagnum-lichen and composite flathummocky subshrub-moss-lichen bogs of lacustrine-alluvial plains with patches of oligotrophic bogs.

The northern-taiga and transitional (to northern taiga) dark-coniferous-pine-larch forests forming part of the group of geoms of hydrolithomorphic sandy pitted and alluvial plains have been transformed largely under the action of pyrogenic, factors. They are larch- Siberian stone pine-pine, larch-pine- and pine-larch true moss-lichen and lichen forests, at the location of which there are emerging uneven-aged tree stands or sparse stands. A decrease in percentage of forest land on the northern territories, specifically in the upper reaches of the Kazym river, leads to successional changes: shallowing, overgrowing and swamping of large kales. Thus, the surroundings of Lake Numto are developing eutrophic and meso-oligotrophic sequences of sedge-cottongrass-sphagnum bogs which are being gradually to promote by dwarf birch-sphagnum-lichen and lichen-subshrub complexes, which promotes the expansion of the areas occupied by tundra-bog landscapes.

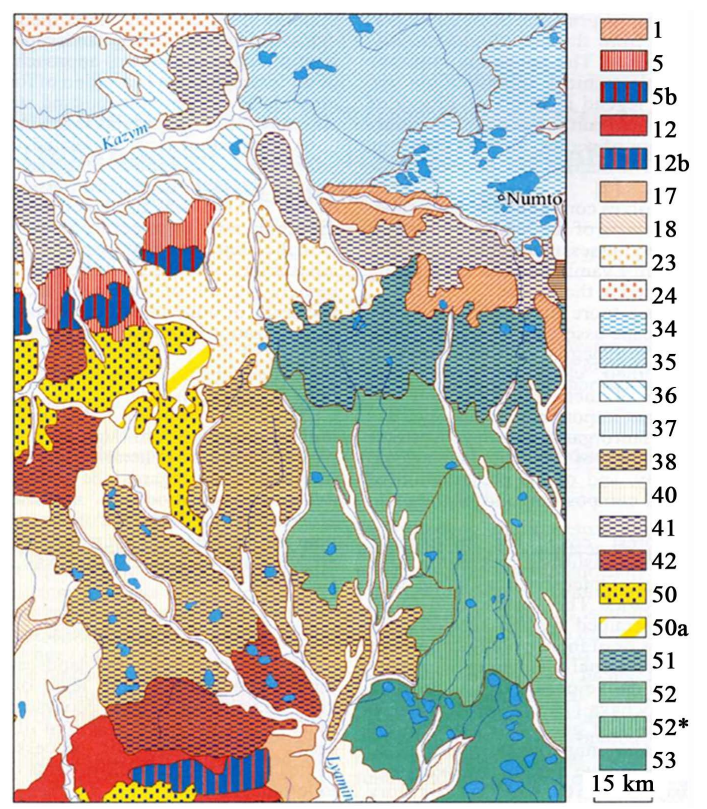

Figure 2. Of the landscape-assessment map of northwestern of part Western Siberia, of interfluves Kazym-Lyamin rivers (for using scaled to up 1:1,500,000). 


\section{Legend:}

ARCTO-BOREAL NORTH-ASIAN TYPEOF NATURAL ENVIRONMENT NORTHERN-SIBERIAN PLAINCONTINENTAL ZONAL-CRYOSPHERIC INTERACTION CLASS OF GEOMS

\section{SUBARCTIC PERMAFROST TUNDRA-LIGHT-CONIFEROUS-OPEN WOODLAND GROUPS OF} GEOMS

NORTHERN-TAIGA ELEVATION-PLAIN LIGHT-CONIFEROUS SUBGROUPS OF GEOMS

Kazym-Polui light-coniferous-open woodland geoms

I. Northern-taiga light-coniferous drained watersheds

Classes of facies

1. Forests of plakor sparse large-pine, pine-larch lichen

URAL-SIBERIAN DARK-CONIFEROUS TAIGA FOOTHILL-PLAIN CLASS OF GEOMS

NORTHERN-URAL SUBSHRUB-OPEN WOODLAND GROUPS OF GEOMS NORTHERN-TAIGA

TERRACE-PLAIN LIGHT-CONIFEROUS SUBGROUPS OF GEOMS

Northern-Ural geoms

II. Terrace-plain light-coniferous with patches of dark-coniferous forests and transitional to northern-taiga

Classes of facies

5. Larch-spruce-Siberian stone pine subshrub-lichen-true moss forests of ridgy water-glacial and glacial plains.

5b. Long-lastingly-derivative larch-spruce-birch, larch-Siberian stone pine-spruce subshrub-lichen-true moss forests at locations of disturbed Siberian stone pine taiga.

\section{TRANSURALIAN FOOTHILL AND TERRACED-PLAIN GROUPS OF GEOMS}

MIDDLE-TAIGA DARK-CONIFEROUS WATERSHED SUBGROUPS OF GEOMS

Transuralian geoms

V. Middle-taiga dark-coniferous weakly drained (fixed) watersheds

Classes of facies

12. Spruce-Siberian stone pine foxberry-true moss forests of low plakor watersheds.

12b. Long-lastingly-derivative spruce-birch, Siberian stone pine-spruce-birch, birch-Siberian stone pine-spruce grass-true moss forests at locations of disturbed Siberian stone pine taiga.

Ob-Irtysh light-coniferous geoms

VII. Coniferous lithomorphic of sandy terraced plains

Classes of facies

17. Forests of sandy plains, pine coniferous with dark-coniferous canopy layer, true moss-lichen.

18. Along-valley pine subshrub-lichen-true moss forests with dark conifers.

NORTH-ASIAN PERMAFROST INTRA CONTINENTALCLASS OF GEOMS

LIGHT-CONIFEROUS HYDROLITHOMORPHIC PLAIN (OUTWASH AND ALLUVIAL) GROUPS OF GEOMS

LIGHT-CONIFEROUS SANDY DRAINED PLAIN SUBGROUPS OF GEOMS

Kazym northern-taiga geoms

$\mathrm{X}$. Light-coniferous with Siberian stone pine northern-taiga and transitional to northern-taiga of elevated and ridgy plains

Classes of facies

23. Forests of gently ridgy sandy plains, larch-pine-Siberian stone pine-pine true moss-lichen with patches of oligotrophic bogs.

24. Forests of elevated sandy plains, larch-pine and pine subshrub-lichen.

WEST-SIBERIAN FLUVIAL-BOG EXCESSIVELYHUMIDIFED TYPE OF NATURAL ENVIRONMENTARCTO-BOREAL OPEN WOODLAND-BOG CLASS OFGEOMS

SUBARCTIC PERMAFROST FLAT-HUMMOCKY BOG AND OPEN WOODLAND-BOG GROUIPS OF GEOMS

FLUVIAL-BOG-PERMAFROST SUBGROUPS OF GEOMS

Polui-Kazym northern-taiga geoms

XVIII. Watershed flat-hummocky bogs of autonomous development (cryohydromorphic)

Classes of facies

34. Bogs of flat lake-filled plains, flat-hummocky dwarf birch-sphagnum-lichen. 
35. Bogs of lake-filled plains, large-hummocky subshrub-moss-lichen on mounds, sedge-cotton-grasssphagnum in mires.

36. Bogs of lacustrine-alluvial plains, composite flat-hummockysubshrub-lichen with patches of flat-convex raised bogs.

XIX. Bog-forest valley-terrace

Classes of facies

37. Bogs of above-floodplain terraces forested oligotrophic subshrub-sphagnum combined with "ryams". BOREAL OLIGOTROPHIC-BOG BLANKET-WATERSHEDCLASS OF GEOMS

AUTOMORPHIC INTERFLUVIAL (OB-IRTYSH) BOG AND FOPREST-BOG GROUPS OF GEOMS CONVEX OLIGOTROPHIC BOGS OF AUTONOMOUS DEVELOPMENT (SUBGROUPS OF GEOMS)

Ob-Irtysh bog geoms

XX. Watershed of oligotrophic bogs of optimal development

Classes of facies

38. Bogs of watersheds, treeless oligotrophic (sedge-sphagnum) and ridgy-lakelet, ridgy-lakelet-pitted mesooligotrophic bogs.

39. Watershed-slope oligotrophic ridgy-pitted bogs and "ryams".

40. Along-valley eutrophic-meso-oligotrophic bogs with patches of mixed-dark-coniferous swamped forests in marginal zones.

WEAKLY DRAINED WATERSHEDS WITH FOREST-BOG COMPLEXES AND TAIGA AMIDST BOGS (GROUPS OF GEOMS)

NORTHERN-TAIGA WATERSHED FOREST-BOG COMPLEXES AND PATCHES OF TAIGA AMIDST BOGS (SUBGROUPS OF GEOMS)

Kazym northern-taiga forest-bog geoms

XXI. Northern-taiga light-coniferous sparse terrace-plain combined with large-hummocky bogs

Classes of facies

41. Open woodlands amidst moderately hummocky bogs along the river valleys and terraces, larch-pine lichen-subshrub-moss.

MIDDLE-TAIGA WATERSHED FOREST-BOG COMPLEXES AND PATCHES OF TAIGA FOREST AMIDST BOGS (SUBGROUPS OF GEOMS)

Ob-Irtysh middle-taiga forest-bog geoms

XXII. Middle-taiga forest-bog weakly drained (fixed) watersheds and areas of taiga amidst bogs

Classes of facies

42. Bogs of marginal zones of watersheds, eutrophic-meso-oligotrophic and pine-subshrub-sphagnum "ryams" (weakly drained bog series).

SUBBOREAL (OB-IRTYSH) BOG-FOREST AND TAIGA (OF ALONG-RIVER DRAINAGE) CLASS OF GEOMS TERRACE AND ALONG-VALLEY MEADOW-FOREST, FOREST-MEADOW-BOG AND FOREST-BOG GROUPS OF GEOMS

HYDROMORPHIC WEST-SIBERIAN TAIGA SUBGROUP OF GEOMS

Ob-Irtysh geoms of along-river plains and terraces

XXVII. Light-coniferous lacustrine-alluvial plains (lithomorphic taiga of along-river drainage)

Classes of facies

50. Along-river plains and terraces, pine with dark-conifers, subshrub-true moss and pine lichen forests combined with oligotrophic bogs.

50a. Short-lasting-derivative pine-birch, birch-pine, pine with birch, small grass-true moss forests of along-river plains and terraces.

LACUSTRINE-FLUVIAL INTRA-ASIAN CLASS OF GEOMS ALLUVIAL-PLAIN (ZONE OF EXCESSIVE HUMIDIFICATION) BOG-LAKE GROUPS OF GEOMS

NORTHERN-TAIGA LACUSTRINE-CRYOSPHERIC FOREST-BOG SUBGROUPS OF GEOMS

Surgut forest-bog geoms

XXVIII. Lacustrine-alluvial plain with flat-convex oligotropic bogs (Surgut-Polesie type)

Classes of facies

51. Watershed-slope flat-convex subshrub-lichen-sphagnum bogs combined with "ryams" and pine-larch 
open woods.

52. Bogs of alluvial plains and flat-convex gentle-slope ridgy-mire-lakelet

52*. Grass-moss quaking bogs amidst flat-convex ridgy-lakelet oligotrophic bogs of the middle parts of heavily lake-filled plains.

53. Bogs of large lacustrine depressions, oligotrophic, hummocky-pitted, forested by pine in the stage of destruction.

The unique features of this territory are the ridgy elevated water-glacial and glacial denudated plains with larch-spruce-Siberian stone pine subshrub-lichen-true moss and lichen-true moss-subshrub forests. It is a modification of the middle-taiga spruce-Siberian stone pine true-moss forests which is distinguished by someinclusion of larch in the composition of the forest stand, with a considerable inclusion of lichens occurring in the grasssubshrub layer. As is the case with thesouthern-taiga subzone, the emergence of such plains is associated with the zones of contact that are represented by bog and forest-bog, largely oligotrophic, complexes.

About 35\% - 40\% of such forests were affected by fires; therefore, the vegetation of disturbed landscapes has been replaced by long-lastingly-derivative larch-spruce-birch and birch-larch-Siberian stone pine-spruce subshrub-lichen-true moss forests. However, the areas of such landscapes for the territory under consideration are very small, so that in the event of a transformation of the bog geosystems, they may well be assigned to partial systems of replacement by the more resistant (in this area) larch-spruce lichen-true moss complexes.

The northeastern part of the interfluve is marked by alluvial-plain bog-lake groups of geoms that are represented by facies classes of flat-convex oligotrophic ridgy-lakelet bogs of the Surgut-Polesie type.

In the southern part of the Kazym-Lyamin interfluve, the subgroups of geoms of middle-taiga dark-coniferous weakly drained watersheds include plakor spruce-Siberian stone pine subshrub- and foxberry-true moss groups of facies. The along-river sandy plains and terraces are characterized by pine true moss-lichen forests.

Changes in species composition and structure of forest vegetation on low loamy (fixed) watersheds and terraces due to tree felling in large areas caused transpiration to decrease and negatively affected the water exchange with the adjacent territory. Because of this, there emerged the swamping process of gentle slopes of the watersheds and terraces, drainage was impaired, and backwater effects were enhanced, which promoted successional changes, namely swamping of river valleys from the cutover area to the river-heads.

Particularly dangerous are the cutover areas formerly occupied by pine and dark-coniferous forests on the moderately high, narrow terraces and along-river plains where the forest vegetation can be totally destroyed in the wake of the swamping process.

Thus the landscapes of the Siberian stone pine taiga on weakly drained (fixed) watersheds are not only unique in their floristic and resource components, but they also have a high functional significance as the stabilizers of swamping processes.

\section{Conclusions}

On one hand, the landscape-assessment map reflects a high level of regional-planetary generalization of natural geosystems at the level of groups and classes of geoms; on the other hand, it represents factoral-dynamic series and main elements of the recovery-age successional dynamics of taiga geosystems at the topological level of study.

In the northern taiga subzone, for example, the emergence of larch-spruce-Siberian stone pine forests is associated with the zones of contacts comprising largely bog complexes. In the case of transformation of bogs, they can be assigned to partial systems of substitution for the more resistant (in this area) larch-spruce lichen-true moss complexes.

Within the frames of the approach outlined above, the map makes it possible to identify ecologically relatively "safe" classes of facies that combine natural complexes where the damage done by negative anthropogenic impacts can be minimized on the basis of their natural resistance to a particular factor of disturbance. For instance, the damage caused by felling in areas of Siberian stone pine-spruce small grass-true moss forests on drained watersheds of the Belogorskii mainland will be less severe when compared with felling of spruce-Siberian stone pine forests on weakly drained (fixed) watersheds, because the Siberian stone pine-spruce forests on the mainland have a shorter recovery cycle (180 - 200 years), and the swamping process occurs only rarely there.

In the future, on the basis of landscape-assessment maps it will be possible to develop the forecasting landscape plan highlighting the most sensitive (to anthropogenic impacts) landscapes and the most significant landscapes from the standpoint of their environment-protective functions. Landscape mapping and planning will help to 
timely prevent and forecast the magnitudes of disturbances to natural environment using, as the basis, a package of optimal nature-conservation measures and target-oriented technogenic and anthropogenic impact.

Furthermore, general-purpose maps provide better insight into global and regional changes in the structure of landscape and vegetation cover and serve as a basis for zoning and regionalization of the territory for purposes of its further efficient economic utilization, conservation and rehabilitation of native landscapes, and for compilation of assessment-forecasting maps for landscape disturbances in the area covered by mapping.

\section{References}

[1] Sochava, V.B. (1978) An Introduction to the Theory of Geosystems. Nauka Press, Novosibirsk.

[2] Mikheev, V.S. (1987) Problems of Supporting Geographical Forecasts, in Landscape-Geographical Support of Comprehensive Problems of Siberia. Nauka Press, Novosibirsk.

[3] Suvorov, E.G., Semenov, Yu.M. and Novitskaya, N.I. (2009) The Landscape-Assessment Map for the Asian Part of Russia-The Principles and Methodological Aspects of Charting. Geografiya i prirod, 4, 5-10.

[4] Kuz'menko, E.I. and Mikheev, V.S. (2008) The Ecologo-Geographical and Cartographic Foundations of a Comprehensive Study of Siberia's Forests. Academic Publishing House "Geo" Press, Novosibirsk.

[5] Belov, A.V., Lyamkin, V.F. and Sokolova, L.P. (2002) Cartographic Study of the Biota. Oblmash-Inform Press, Irkutsk.

[6] Kuzmenko, E.I. and Smolonogov, E.P. (2000) Forest Ecosystems of the Middle and Southern Taiga of the West-Siberian Plain Structure and Spatiotemporal Dynamics. SO RAN Press, Novosibirsk.

[7] Berlyant, A.M. (1985) The Map as a Second Language of Cartography. Prosveshchenie Press, Moscow. 